\title{
Oscillation theorems for third order neutral differential equations
}

\section{BLANKA BACULÍKOVÁ and J. DŽURINA}

\section{ABSTRACT.}

The aim of this paper is to study the asymptotic properties and the oscillation of the third order neutral differential equations

$$
\left(r(t)[x(t)+p(t) x(\tau(t))]^{\prime \prime}\right)^{\prime}+q(t) x(\sigma(t))=0 .
$$

Obtained results are based on the new comparison theorems, that permit to reduce the problem of the oscillation of the third order equation to the oscillation of the couple of the first order equation. Obtained comparison principles essentially simplify the examination of the studied equations.

DEPARTMENT OF MATHEMATiCS

FACULTY OF ELECTRICAL ENGINEERING AND INFORMATICS

TECHNICAL UNIVERSITY OF KOŠICE

LETNÁ 9, 04200 KoŠICE, SLOVAKIA

E-mail address: blanka.baculikova, jozef.dzurina, @tuke.sk 